相装置とかなり改善された装置（テトロード管による管 電圧制御定電圧方式）之比較検討した.

測定結果，非直線性の問題では三相装置は管電流 200 $\mathrm{mA}$, 曝射時間 $3 \mathrm{~ms}$ で $22 \sim 68 \%$, 定電圧装置は $13 \sim 16 \%$ 增大である、シネ撮影時の濃度变化は定電庄装置は管電 压，管電流共脈動がごく僅かなため三相装置に比べ少な い.

〔結論】定電圧装置の出現により軽負荷を除けば $1 \mathrm{~ms}$ の曝射時間でも $20 \%$ 程度の増大之なり極短時間曝射む実 用領域に入ってきた。 また管電压の立ち上り，立ち下り の問題む㪕負荷時にお就る管電圧の立ち下り時間による 影響の方が大きくなってきた。

\section{X線高電圧装置二次側制御方式の違いによる装置 の性能評価}

\section{炤和大学病院中央放射線部}

○小田正記・中沢靖夫・新田 勝

〔目的】二次側制御方式の異なるX線高電圧装置 3 台 の性能を，管電圧・管電流の精度と再現性，タイマの測 定，立ち上がり時間の測定，短時間領域でのX線出力の 直線性, 出力と線質之言う項目について比較検討し, 性 能を評㑛する。

〔絬果】管電圧，管電流，タイマは，どの装置も規 格を満たしていたが，DC-150Cで調整の甘さが見られ た。直線性では CPG-20, SHO-150G とも10\%以内で, DC-150C は，最大 $35 \%$ あ゙あり，立ち上がり時間はそれぞ れ， $160 \mu \mathrm{sec}, 80 \mu \mathrm{sec}, 533 \mu \mathrm{sec}$ であった. 線質は立ち 上がりのサージ電压の影響と，管電压波形のリップルの 影響が見られた。

\section{X線出力の再現性と管電流に対する直線性}

東京部会X線装置研究会立川其済病院

○上遠野昭・竹内金枝

炤和矦大病院

新田 勝・一于鉄昭

杏林大学病院 堀江慶一郎

関東遇信病院

高毛礼篤子・山下 緑

日本鋼管病院 斉藤一彦

東邦大学大橋病院

宮崎 茂他会員一同

[目的〕X線装置汇対しダイナミックスタディを行い X線出力の再現性乙管電流任対する直線性の検澍を行っ たので報华する。

〔結果】 X線出力の再現性は $\mathrm{CV}$ で0〜0. 022. 直線性 の变動好定電圧装置士5\%以内，単相 2 ピーク装置 \pm 10
$\%$ 以内, 三相 12 ピーク装置士 $20 \%$ 以内であった. $(80 \mathrm{kV}$ 時)

〔結論】X線出力の再現性は良好であったが，直線性 についてはいまだ問題を残す。面線性の不良は前示值之 の愦差によるものと, 負荷の変化による管電压脈動率の 変動やケーブルの浮搌容量などの装置の基本特性による あのに分壮られる.

\section{2. 高周波インバータ方式X線発生装置（第 1 報）}

東芝那須工場 CT 技術部

○田中 茂・旨田忠候・高木 兽 同医用機器放射線技術部 土屋 明・石山文雄

X線発生装置においても，小型・軽量化ならびに信頼 性向上が望まれている.その一つの試みとして, 高周波 インバータ方式によるX線発生装置を試作し，機能試験 を行っている．基礎研究段階であるが，現在までの状沉 を第 1 報として報告する，共振型インバータ方式で，高 压トランスに印加する電圧の周波数を高周波化すること により，高压トランスが約1/10（試作例）と小型・軽量 化が期待できる. 現状 $90 \mathrm{kV}, 100 \mathrm{~mA}, 5 \mathrm{~ms}$, 管電圧立上 り時間 1〜2 ms, 管電压リップル $5 \sim 10 \% \mathrm{p}-\mathrm{p}$ のパルス出 力が得られている. 合わせてX線スペクトルシミュレー ションにより, 高周波りップルの平均エネルギー, 線量 への影響等を検討している.

403. 多周波による小形全波装置の性能改善について (第 6 報)

済生会横浜沁南部病院

○河内千代子・佐野常啨・林幸一 鈴木靖範・中野博美・蕗 利彦 東克医療用品 K.K.

井上清孝・小松崎貢

〔目的〕ポータブル撮影において, 尚一層の装置の軽 量小形化之画質の向上加必要之考えられ，現在の移動型 小形X線装置 $(120 \mathrm{p}-\mathrm{c})$ の高圧トランス印加電圧をイン バータで $500 \mathrm{~Hz}$ に要換し, ヘッド部分の軽量小形化を 図った。

〔方法] $120 \mathrm{p}-\mathrm{c}$ 装置と試作装置について, 半価層, 蛍光波形, アクリルの透過線量, MTF, H-D 曲線, 臨床 写真等で, 比較検討した.

〔結果〕ヘッド部分の総重量は約 $2 / 3$ 亿軽量化され,装 置自体の小形化も可能にした。一般電源でも管電圧脈動 が小さく線質が硬くなり, 同一条件で高い線量率が得ら れ，透過線量が $500 \mathrm{~Hz}$ の場合，約 2 倍であった. 露出時 間の短縮，コントラスト向上で臨床的にも良好であった。 